\title{
Deletion of Fas protects islet beta cells from cytotoxic effects of human islet amyloid polypeptide
}

\author{
Y. J. Park • S. Lee • T. J. Kieffer • G. L. Warnock • \\ N. Safikhan • M. Speck • Z. Hao • M. Woo • L. Marzban
}

Received: 15 September 2011 / Accepted: 9 December 2011 / Published online: 1 February 2012

(C) Springer-Verlag 2012

\begin{abstract}
Aims/hypothesis Islet amyloid, which is mainly composed of human islet amyloid polypeptide (hIAPP), is a pathological characteristic of type 2 diabetes and also forms in cultured and transplanted islets. We used islet beta cells as well as two ex vivo models of islet amyloid formation, cultured human islets and $\mathrm{h} I A P P$ expressing transgenic mouse islets with or without beta cell Fas deletion, to test whether: (1) the aggregation of endogenous hIAPP induces Fas upregulation in beta cells; and (2) deletion or blocking of Fas protects beta cells from amyloid toxicity.
\end{abstract}

Electronic supplementary material The online version of this article (doi:10.1007/s00125-012-2451-2) contains peer-reviewed but unedited supplementary material, which is available to authorised users.

Y. J. Park · S. Lee · T. J. Kieffer · G. L. Warnock • N. Safikhan •

M. Speck $\cdot$ L. Marzban $(\square)$

Department of Surgery, Faculty of Medicine,

University of British Columbia, Jim Pattison Pavilion,

Vancouver General Hospital,

$910 \mathrm{~W} 10$ th Ave,

Vancouver, BC, Canada V5Z 4E3

e-mail: lucy.marzban@ubc.ca

\section{T. J. Kieffer}

Department of Cellular and Physiological Sciences,

Faculty of Medicine, Life Sciences Institute,

University of British Columbia,

Vancouver, BC, Canada

Z. Hao $\cdot$ M. Woo

Department of Medicine, University of Toronto,

Ontario Cancer Institute, St Michael's Hospital,

Toronto, ON, Canada
Methods INS-1, mouse or human islet cells were cultured with hIAPP alone, or with amyloid inhibitor or Fas antagonist. Non-transduced islets, and human islets or hIAPPexpressing mouse islets transduced with an adenovirus that delivers a human proIAPP-specific small interfering RNA (siRNA) (Ad-ProhIAPP-siRNA) were cultured to form amyloid. Mouse islets expressing h $I A P P$ with or without Fas were similarly cultured. Beta cell Fas upregulation, caspase3 activation, apoptosis and function, and islet IL-1 $\beta$ levels were assessed.

Results hIAPP treatment induced Fas upregulation, caspase3 activation and apoptosis in INS-1 and islet cells. The amyloid inhibitor or Fas antagonist reduced apoptosis in hIAPP-treated beta cells. Islet cells with Fas deletion had lower hIAPP-induced beta cell apoptosis than those expressing Fas. Ad-ProhIAPP-siRNA-mediated amyloid inhibition reduced Fas upregulation and IL-1 $\beta$ immunoreactivity in human and $\mathrm{h} I A P P$-expressing mouse islets. Cultured $\mathrm{h} I A P P$-expressing mouse islets with Fas deletion had similar amyloid levels, but lower caspase-3 activation and beta cell apoptosis, and a higher islet beta:alpha cell ratio and insulin response to glucose, compared with islets expressing Fas and $\mathrm{h} I A P P$.

Conclusions/interpretation The aggregation of biosynthetic hIAPP produced in islets induces beta cell apoptosis, at least partially, via Fas upregulation and the Fas-mediated apoptotic pathway. Deletion of Fas protects islet beta cells from the cytotoxic effects of endogenously secreted (and exogenously applied) hIAPP.

Keywords Amylin · Amyloid · Beta cell apoptosis · Fas receptor · Islet amyloid polypeptide · Type 2 diabetes 


\section{Abbreviations}

Ad-Cont-siRNA

Ad-Proh $I A P P$-siRNA

HFIP

hIAPP

rIAPP
An adenovirus that delivers a random non-specific small interfering RNA

An adenovirus that delivers a human pro $I A P P$-specific small interfering RNA

1,1,1,3,3,3-Hexafluoro-2-propanol

Human islet amyloid polypeptide Rat islet amyloid polypeptide

\section{Introduction}

Islet amyloid formation is a pathological characteristic of the pancreas in type 2 diabetes and contributes to progressive beta cell dysfunction and death in this disease [1-3]. Islet amyloid also forms in human islets during culture [4] and following transplantation into mouse models of type 1 diabetes [5-7]. Importantly, widespread amyloid deposition was reported in human islets that had been transplanted into a patient with type 1 diabetes [8]. Amyloid formation in transplanted islets is associated with beta cell dysfunction and recurrence of hyperglycaemia in animal models of type 1 diabetes [7, 9]. Thus, in addition to its role in the pathogenesis of type 2 diabetes, islet amyloid formation may also play a role in islet graft failure in patients with type 1 diabetes.

Islet amyloid is mainly formed by the aggregation of islet amyloid polypeptide (amylin) [10, 11], a 37-amino acid hormone that is co-localised and co-secreted with insulin in response to beta cell secretagogues [12, 13]. Despite considerable study during the past decade, it is still not clear why normally soluble human islet amyloid polypeptide (hIAPP) molecules form toxic aggregates in type 2 diabetes. The following have been proposed to contribute to the aggregation of hIAPP molecules in type 2 diabetes: (1) presence of an amyloidogenic sequence in the hIAPP molecule [2, 14]; (2) elevated hIAPP production and secretion from beta cells, associated with an increased demand for insulin [13, 15]; and (3) defects in trafficking and processing of proIAPP, associated with beta cell dysfunction [13, 15-17]. The rapid formation of amyloid in cultured and transplanted human islets may be related to poor clearance of released hIAPP from beta cells due to the disrupted vasculature [18] and/or to the impaired proIAPP processing and secretion that are associated with beta cell dysfunction induced by islet isolation, culture and transplantation $[13,19]$.

Aggregates of hIAPP, including small oligomeric species, are toxic to beta cells and have been shown to induce beta cell dysfunction and apoptosis in isolated human islets [4, 20]. Previous in vitro studies have suggested different mechanisms for the beta cell apoptosis mediated by hIAPP aggregates, including disruption of membrane integrity and

formation of non-selective ion-channel-like structures [21-23], activation of the caspase pathways [24-27] and interaction of hIAPP fibrils with components of beta cell membranes such as heparan sulphate proteoglycans $[28,29]$ or touch receptors [30]. It is, however, not clear which of these mechanism(s) contribute(s) to hIAPP-induced beta cell death in primary islets, in which the level of endogenously produced hIAPP $(\mathrm{pmol} / \mathrm{l})$ is several fold lower $[1$, $31]$ than that used in vitro $(\mu \mathrm{mol} / \mathrm{l})$. Recent studies suggest that endoplasmic reticulum stress [32-34], oxidative stress [35] and disruption in the autophagy-lysosomal pathway [36] due to formation of intracellular hIAPP aggregates also contribute to the cytotoxic effects of hIAPP. It therefore appears that, at least in vitro, hIAPP-induced beta cell apoptosis involves several mechanisms, some of which may share the same apoptotic signalling pathways.

Fas (CD95/APO-1) is a transmembrane receptor protein belonging to the tumour necrosis factor superfamily of receptors [37-39]. The extrinsic apoptotic pathway initiated by the interaction between Fas and Fas ligand (FasL/CD95L) has been implicated in autoimmune-mediated beta cell death in type 1 diabetes [40-42] and non-immune-mediated beta cell death in type 2 diabetes [43,44]. Islet beta cells constitutively produce Fas ligand, but do not normally produce Fas at detectable levels [40, 43]. However, conditions associated with beta cell stress, such as exposure to elevated glucose, leptin or cytokines (e.g. IL-1 $\beta$ ), can induce upregulation of Fas and apoptosis in isolated human islets [43-45].

In the present study, we tested whether hIAPP aggregates derived from biosynthetic hIAPP secreted from islets can induce beta cell apoptosis via upregulation of Fas. We used islets from humans and transgenic mice with beta cellspecific hIAPP expression and Fas deletion, as well as transformed and primary islet beta cells, to investigate the role of Fas in mediating islet amyloid-induced beta cell toxicity and to examine whether deletion of Fas can protect beta cells from hIAPP aggregates derived from endogenously secreted and exogenously applied hIAPP.

\section{Methods}

Materials Synthetic hIAPP and rat islet amyloid polypeptide (rIAPP) (1-37) were from Bachem (Torrance, CA, USA) and Fas antagonist (Kp7-6) was from EMD Chemicals (Gibbstown, NJ, USA). Thioflavin S, dithizone, BSA, Congo red, HEPES buffer, 2-mercaptoethanol, sodium bicarbonate, poly-L-lysine, Triton X-100, DMSO, 1,1,1,3,3,3hexafluoro-2-propanol (HFIP), tribromoethanol and collagenase (Type XI) were obtained from Sigma-Aldrich (Oakville, ON, Canada). RPMI-1640, FBS, penicillin, streptomycin, gentamycin, cell dissociation buffer enzyme-free Hanks'-based solution, Ham's-F10, trypsin-EDTA and 
glutamax were from Invitrogen Canada (Burlington, ON, Canada). CMRL culture medium was from Mediatech (Herndon, VA, USA).

Human islets Human islets isolated from deceased pancreas donors were provided by the Ike Barber Human Islet Transplant Laboratory (Vancouver, BC, Canada) in accordance with approved procedures and guidelines of the Clinical Research Ethics Board of the University of British Columbia. Hand-picked human islets (purity $>90 \%$ ) were cultured for 7 days at $37^{\circ} \mathrm{C}$ in $\mathrm{CMRL}$ supplemented with $11.1 \mathrm{mmol} / 1$ glucose, $10 \%$ (vol./vol.) FBS, $50 \mathrm{U} / \mathrm{ml}$ penicillin, $50 \mu \mathrm{g} / \mathrm{ml}$ streptomycin and $50 \mu \mathrm{g} / \mathrm{ml}$ gentamycin. Culture procedures were in humidified $5 \% \mathrm{CO}_{2} / 95 \%$ air.

Animal models Hemizygous $\mathrm{C} 57 \mathrm{BL} / 6 \mathrm{~h} I A P P$ transgenic mice with beta cell-specific $\mathrm{h} I A P P$ expression $\left(\mathrm{h} I A P P^{+/}\right.$) were kindly provided by S. Kahn (Department of Medicine, University of Washington, Seattle, WA, USA) and maintained by breeding with DBA/2J mice (Jackson Laboratory, Bar Harbor, ME, USA). Male $\mathrm{h} I A P P$-expressing mice form islet amyloid in vivo and develop diabetes in the presence of a predisposing factor such as a high-fat diet [46]. Mice with beta cell-specific Fas deletion (RIP cre $^{+} \mathrm{Fas}^{\mathrm{fl} / \mathrm{fl}}$ ) were generated using the Cre/loxP recombinase system as previously described [47]. RIP $\mathrm{Cre}^{+} \mathrm{Fas}^{\mathrm{fl} / \mathrm{fl}}$ mice were maintained by breeding RIP $\mathrm{Cre}^{+} \mathrm{Fas}^{+/ \mathrm{fl}}$ mice from the Ontario Cancer Institute. To generate mice with beta cell-specific $\mathrm{h} I A P P$ expression and Fas deletion, hIAPPP ${ }^{+-}$mice were cross-bred with $\mathrm{RIPCre}^{+} \mathrm{Fas}^{\mathrm{fl} / \mathrm{fl}}$ mice to produce RIP $\mathrm{Cre}^{+} \mathrm{Fas}^{+/ \mathrm{fl}} / \mathrm{h} I A P P^{+/-}$mice, which were then bred together to generate RIP $\mathrm{Cre}^{+} \mathrm{Fas}^{\mathrm{fl} / \mathrm{fl} /}$ $\mathrm{h} I A P P^{+}$and RIP $\mathrm{Cre}^{+} \mathrm{Fas}^{++} \mathrm{h} / A P P^{+}$mice. The first generation of these offspring was used for the studies. Islets from $\mathrm{RIPCre}^{+} \mathrm{Fas}^{\mathrm{f} / \mathrm{fl}}$ animals have normal islet mass and enhanced insulin secretion [47]. All mice were fed mouse chow containing 9\% (wt/wt) fat (Purina 5021; LabDiet, Richmond, IN, USA). Animals were cared for in accordance with the Guidelines and Principles of Laboratory Animal Care and the standard procedures established by the Canadian Council on Animal Care and the University of British Columbia's Animal Policy and Welfare Committee.

Mouse islet isolation and culture Islets from wild-type $\left(\mathrm{h} I A P P^{-/-}\right.$) and $\mathrm{h} I A P P^{+/-}$mice (8-12 weeks old) or different genotypes of RIP $\mathrm{Cre}^{+} \mathrm{Fas} / \mathrm{h} I A P P$ mice $(8-18$ weeks) were isolated as previously described [27] with some modifications. Briefly, animals were anaesthetised with tribromoethanol $(0.02 \mathrm{ml} / \mathrm{g}$ body weight, i.p.) and killed by cervical dislocation. The abdominal cavity was opened and ice-cold collagenase (Type XI; Sigma) in $2.5 \mathrm{ml}$ calcium-free Hanks' solution (final concentration 1,000 U/ml) was injected via the common bile duct. The removed pancreas was incubated with collagenase and Hanks' solution $(1,000 \mathrm{U} / \mathrm{ml})$ in a shaker water bath $\left(14 \mathrm{~min}, 37^{\circ} \mathrm{C}, 120 \mathrm{rev} / \mathrm{min}\right)$. Digestion was stopped by addition of ice-cold Hanks' solution containing $1 \mathrm{mmol} / 1 \mathrm{CaCl}_{2}$. Digested pancreatic tissues were rinsed with the same solution, resuspended in Ham's-F10 and filtered through a $70 \mu \mathrm{m}$ mesh cell strainer (BD Biosciences, Oakville, ON, Canada). Hand-picked islets (purity $>95 \%$ ) were cultured in Ham's-F10 supplemented with $16.7 \mathrm{mmol} / 1$ glucose, $0.5 \%$ (wt/vol.) BSA and antibiotics as described for human islets. For all islet studies, the culture medium was changed every 2 days.

Adenoviral transduction of human and mouse islets As previously described [4], we used human islets or hIAPPexpressing mouse islets transduced overnight with an adenovirus that delivers a human proIAPP-specific small interfering RNA (Ad-Proh $I A P P$-siRNA) (multiplicity of infection 20), or transduced with an adenovirus that delivers a random non-specific small interfering RNA (Ad-ContsiRNA) (multiplicity of infection 20). Adenoviral-siRNA transduced human or hIAPP-expressing mouse islets were then rinsed and cultured in CMRL $(11.1 \mathrm{mmol} / \mathrm{l}$ glucose, 7 days) or Ham's-F10 (16.7 mmol/1, 6 days), respectively.

Transformed beta cells and islet cell culture INS-1 (832/13) cells, a transformed rat beta cell line, were a gift from $\mathrm{C}$. Newgard (Duke University Medical Center, NC, USA). Cells were grown in RPMI-1640 containing $11.1 \mathrm{mmol} / 1$ glucose supplemented with $10 \%$ (vol./vol.) FBS, $50 \mathrm{U} / \mathrm{ml}$ penicillin, $50 \mu \mathrm{g} / \mathrm{ml}$ streptomycin and $50 \mu \mathrm{mol} / 1$ 2-mercaptoethanol. Human or mouse islets $(\sim 200)$ were dissociated as previously described [27] and cell viability assessed by Trypan blue. Islet cells were cultured in 8-well chamber slides (BD Biosciences) pre-coated with poly-L-lysine; the culture process was in CMRL (human) or Ham's-F10 (mouse) containing 5.5 and $10 \mathrm{mmol} / \mathrm{l}$ glucose, respectively.

Treatment studies with hIAPP, Fas antagonist and amyloid binding dye Lyophilised hIAPP or rIAPP was dissolved in HFIP and incubated at room temperature $(1 \mathrm{~h})$; aliquots were frozen $\left(-80^{\circ} \mathrm{C}\right)$ and lyophilised. INS-1 or dispersed islet cells were treated with hIAPP or rIAPP that had been prepared freshly by dissolving lyophilised peptide in medium; they were then cultured for different times as detailed. The amyloid-binding dye Congo red or Fas antagonist Kp76 was added to the culture medium $30 \mathrm{~min}$ before addition of hIAPP at final concentrations of $25 \mu \mathrm{mol} / \mathrm{l}$ and $10 \mathrm{mmol} /$ 1 , respectively.

Assessment of beta cell function in cultured islets Islets $(25$ islets per mouse; duplicate, four to six mice per group) were pre-incubated $(1 \mathrm{~h})$ at $37^{\circ} \mathrm{C}$ in $300 \mu \mathrm{KRB}$ containing $10 \mathrm{mmol} / 1$ HEPES (pH 7.4), 0.25\% (wt/vol.) BSA and $1.67 \mathrm{mmol} / \mathrm{l}$ glucose, followed by $1 \mathrm{~h}$ of incubation in $150 \mu \mathrm{l}$ 
$\mathrm{KRB}$ containing $1.67 \mathrm{mmol} / \mathrm{l}$ glucose (basal insulin release) and by $1 \mathrm{~h}$ of incubation in KRB with $16.7 \mathrm{mmol} / 1$ glucose (stimulated insulin release). Islets were lysed in $100 \mu \mathrm{l}$ of $1 \mathrm{~mol} / 1$ acetic acid and $0.1 \%$ (wt/vol.) BSA lysis buffer, followed by $10 \mathrm{~min}$ incubation at $100^{\circ} \mathrm{C}$. Incubation media and islet lysates were centrifuged and supernatant fractions frozen $\left(-20^{\circ} \mathrm{C}\right)$ until assayed. Insulin and proinsulin levels were measured using mouse-specific insulin and proinsulin ELISA kits (ALPCO Diagnostics, Salem, NH, USA).

Immunolabelling, TUNEL and thioflavin S staining Paraffinembedded islet sections $(5 \mu \mathrm{m})$ were de-waxed, rehydrated and blocked in $2 \%$ (vol./vol.) normal goat and/or donkey serum (Vector Laboratories, Burlingame, CA, USA). Fixed islet sections (following antigen retrieval with citrate buffer) or cells were incubated overnight with guinea pig anti-insulin alone (islets 1:750, cells 1:200; Dako, Carpinteria, CA, USA) or with each of rabbit anti-IL-1 $\beta$ (1:100; Santa Cruz, Santa
Cruz, CA, USA), anti-glucagon (1:750; Dako), anti-cleaved caspase-3 (1:100; Cell Signaling, Pickering, ON, Canada) and anti-Fas (mouse islets 1:50, cells 1:100, Santa Cruz; human islets 1:100, Cell Signaling). Islet sections or cells were then incubated for $1 \mathrm{~h}$ with Texas red-conjugated anti-guinea pig (1:750; Jackson Laboratories, West Grove, PA, USA) and Alexa 488-conjugated anti-rabbit (1:200; Molecular Probes, Eugene, OR, USA). For triple immunostaining, islet cells were immunolabelled overnight for insulin (1:200) and Fas (1:100), followed by incubation with aminomethylcoumarin acetate-conjugated anti-guinea pig (1:200; Jackson) and Texas red-conjugated anti-rabbit (1:100; Jackson), and then with Alexa 488-conjugated cleaved caspase-3 antibody (1:10; Cell Signaling). The specificity of the Fas antibody was evaluated by immunolabelling of IL-1 $\beta$ - or hIAPP-treated INS-1 cells after antibody blocking using recombinant Fas (electronic supplementary material [ESM] Fig. 1). For double insulin and TUNEL or thioflavin S staining, after immunolabelling a

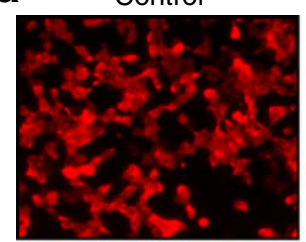

b
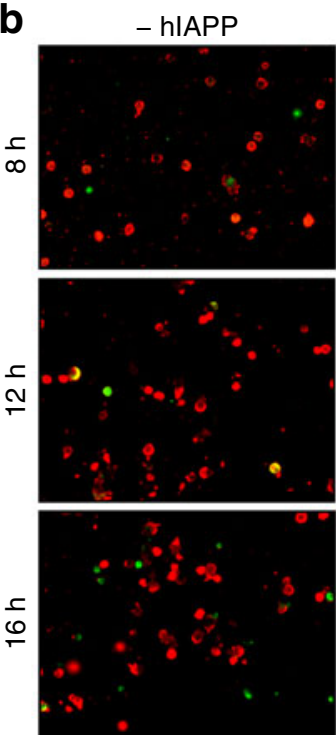

+ rIAPP

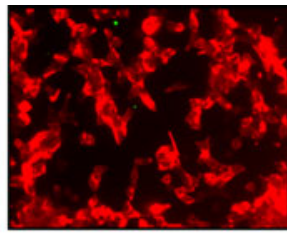

+ hIAPP

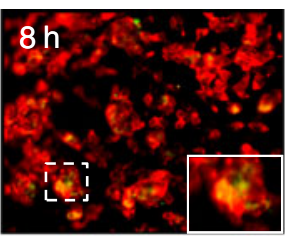

+ hIAPP

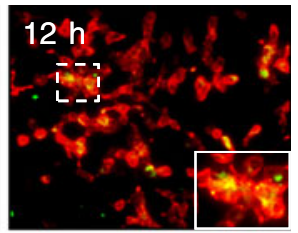

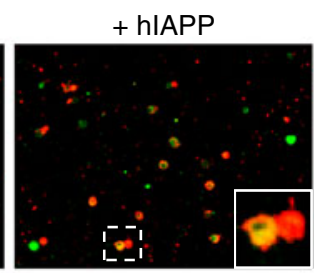
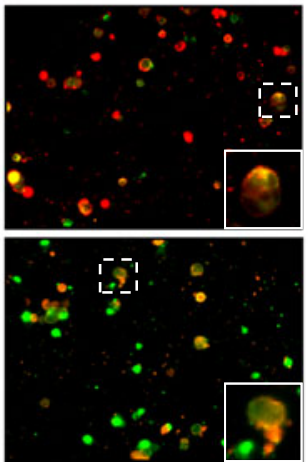

C

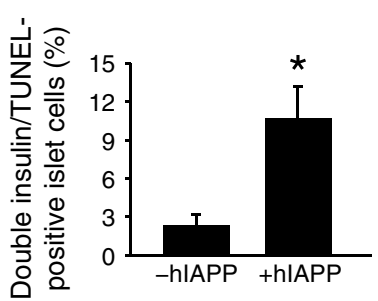

d

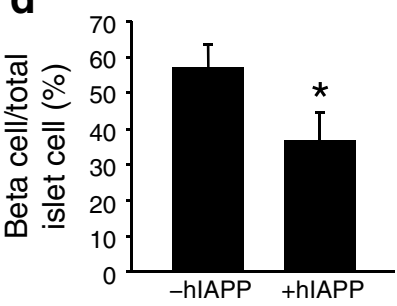

Fig. 1 Exposure to synthetic hIAPP induces Fas upregulation, associated with caspase- 3 activation and apoptosis in INS- 1 and mouse islet beta cells. INS-1 cells and dispersed mouse islet cells were treated with $10 \mu \mathrm{mol} / 1$ synthetic hIAPP or non-fibrillogenic rIAPP (as control) at different time points. a Immunolabelling of INS-1 cells for insulin (red) and Fas (green) after 8 and $12 \mathrm{~h}$ of exposure to hIAPP or rIAPP. b Immunolabelling of dispersed mouse islet cells for insulin (red) and Fas (green), or cleaved (active) caspase-3 (green) following exposure to hIAPP for 8,12 or $16 \mathrm{~h}$. The squares (dashed white lines) denote regions enlarged and depicted as insets at bottom right of the relevant images. c The proportion of TUNEL-positive islet cells and (d) beta cell:total islet cell ratio in dispersed mouse islets following culture with or without hIAPP for $24 \mathrm{~h}$. The proportion of apoptotic beta cells (c) was quantified by manual counting of double insulin- and TUNEL-positive islet cells in a minimum of ten microscopic fields each containing 100 to 150 dispersed islet cells. The beta cell:total islet cell ratio (d) represents the mean of insulin-positive islet cells divided by total islet cells in each microscopic field. Results (c, d) are expressed as means \pm SEM of three independent studies performed in triplicate. ${ }^{*} p<0.05$ by Student's $t$ test vs non-treated group 
for insulin, islet sections (or cells) were incubated for $30 \mathrm{~min}$ at $37^{\circ} \mathrm{C}$ with TUNEL reaction mixture (Roche Diagnostics, Laval, QC, Canada) or for $5 \mathrm{~min}$ at room temperature with $0.5 \%$ (wt/vol.) thioflavin S solution.

Statistical analysis Data are expressed as means \pm SEM. Statistical analyses were performed using one-way ANOVA followed by Newman-Keuls test or by Student's $t$ test as appropriate. A value of $p<0.05$ was taken as significant. All experiments were performed in duplicate or triplicate and repeated at least three times.

\section{Results}

Exogenously applied hIAPP induces Fas upregulation, caspase-3 activation and apoptosis in transformed INS-1 cells and in primary human and mouse islet beta cells Transformed INS-1 cells and dispersed mouse or human islet cells were treated with synthetic hIAPP $(10 \mu \mathrm{mol} / \mathrm{l})$ for 4,8 and $12 \mathrm{~h}$. Fas was not detectable in non-treated INS-1 cells by immunolabelling, but treatment with hIAPP induced Fas upregulation in a time-dependent manner, with low levels of Fas present after $8 \mathrm{~h}$ and higher levels detectable after $12 \mathrm{~h}$
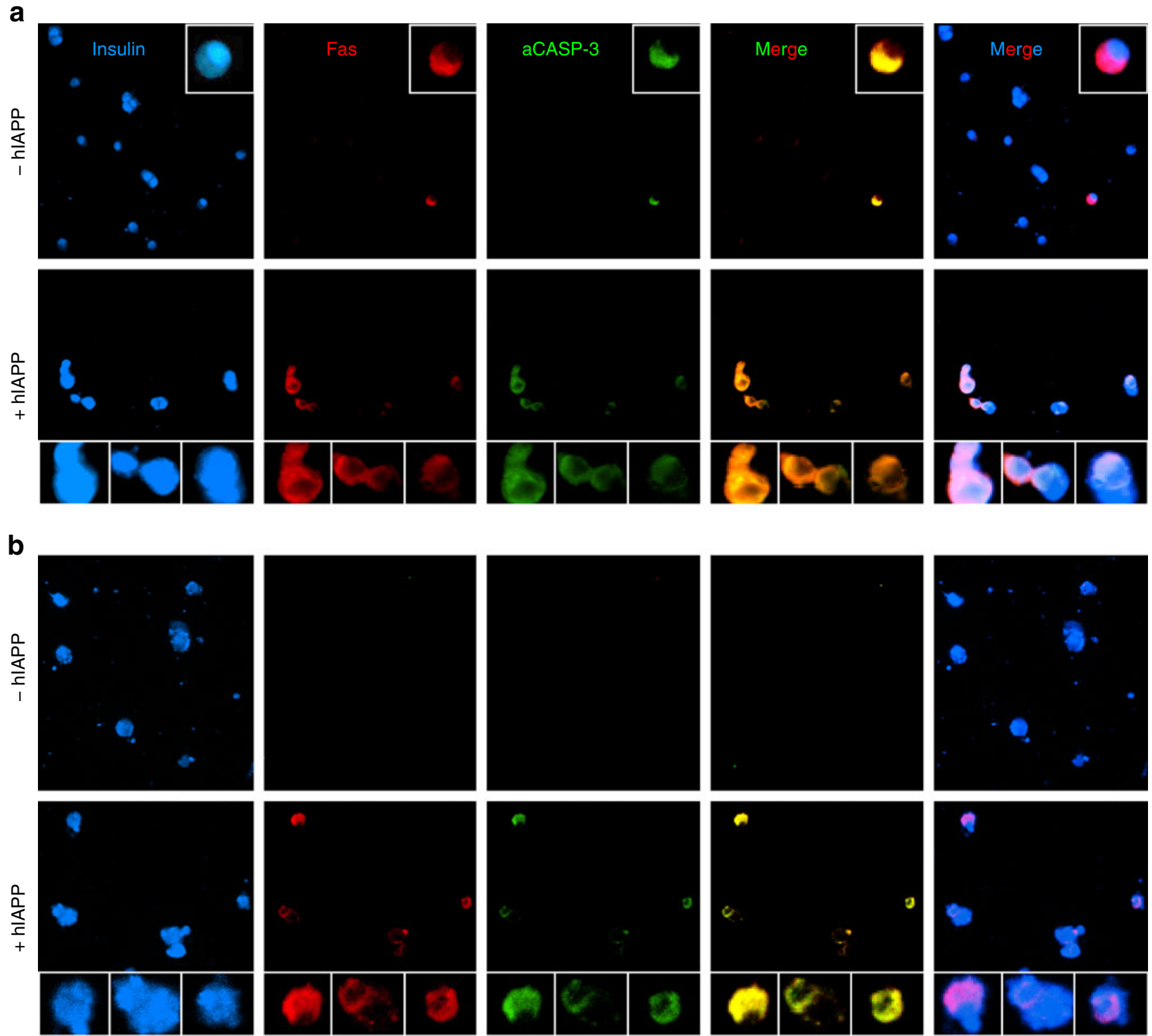

Fig. 2 Co-localisation of Fas and active caspase-3 in human and mouse islet cells treated with synthetic hIAPP. a Dispersed human or (b) mouse islet cells cultured without (control) or with synthetic hIAPP $(10 \mu \mathrm{mol} / \mathrm{l}, 12 \mathrm{~h})$ as indicated were immunolabelled for insulin (blue), Fas (red) and cleaved (active) caspase-3 (aCASP-3) (green). The squares (white outline) denote regions enlarged in each image. Note the higher number of double Fas- and cleaved caspase-3-positive islet beta cells in human and mouse islet cells treated with hIAPP compared with non-treated islet beta cells. Images represent three independent human or mouse studies performed in duplicate 
(Fig. 1a). Treatment with non-fibrillogenic rIAPP did not have any noticeable effect on Fas abundance. Similarly, exogenously applied hIAPP induced Fas upregulation in primary islet cells, mainly in beta cells, this being detectable after 8 and 12 h (Fig. 1b). Upregulation of Fas was associated with an increased number of active caspase- 3 and TUNEL-positive (apoptotic) beta cells (Fig. 1b, c), resulting in a lower islet beta:total cell ratio in hIAPP-treated than in non-treated islet cells (Fig. 1d). The time point of Fas upregulation preceded that of caspase-3 activation (16 h) and apoptosis $(24 \mathrm{~h})$. Moreover, immunolabelling studies showed co-localisation of Fas and active caspase-3 in hIAPP-treated human and mouse islet beta cells (Fig. 2). Unlike INS-1 cells, a low number of Fas-positive beta and non-beta islet cells was present in non-treated dispersed mouse and human islets (Figs $1 \mathrm{~b}$ and 2a).

Preventing the interaction between hIAPP aggregates and beta cells markedly reduces beta cell apoptosis in hIAPPtreated INS-1 cells We examined whether the interaction between hIAPP fibrils and islet beta cells is required for induction of Fas upregulation. INS-1 beta cells were cultured without or with hIAPP or non-fibrillogenic rIAPP (as control) in the presence or absence of the amyloid binding dye, Congo red, for $12 \mathrm{~h}$. We have previously shown that Congo red at this concentration does not have any adverse effects on beta cell survival [27]. Treatment with Congo red markedly reduced Fas upregulation, caspase- 3 activation and apoptosis in hIAPP-treated INS-1 cells (Fig. 3a-c). Treatment with non-fibrillogenic rIAPP did not have any detectable effect on beta cell apoptosis (Fig. 3c).

\section{Blocking or deletion of Fas reduces the beta cell apoptosis} induced by exogenously applied hIAPP INS-1 cells or primary islet cells were cultured with or without synthetic hIAPP in the absence or presence of a Fas antagonist (Kp7-6) for $12 \mathrm{~h}$. INS-1 and primary mouse islet cells treated with hIAPP and the Fas antagonist had significantly lower beta cell apoptosis than cells treated with hIAPP in the absence of the Fas antagonist (Fig. 3b-d). Treatment with the Fas antagonist alone did not have any effect on beta cell apoptosis in non-treated cells (Fig. 3d). Furthermore, dispersed wild-type and RIP $\mathrm{Cre}^{+} \mathrm{Fas}^{\mathrm{f} / \mathrm{fl}}$ mouse islet cells were treated with synthetic hIAPP. There was no significant difference in basal beta cell apoptosis between wild-type and RIP$\mathrm{cre}^{+} \mathrm{Fas}^{\mathrm{fl} / \mathrm{fl}}$ mouse islet cells (Fig. 3e, f). Interestingly, hIAPPtreated RIP $\mathrm{Cre}^{+} \mathrm{Fas}^{\mathrm{fl} / \mathrm{fl}}$ islets had markedly lower beta cell death than hIAPP-treated wild-type islet cells, suggesting that deletion of Fas reduces beta cell death induced by the aggregation of exogenously applied hIAPP.

Inhibition of islet amyloid formation reduces IL-1 $\beta$ levels, Fas upregulation and beta cell apoptosis in human and
hIAPP-expressing transgenic mouse islets Human or $\mathrm{h} I A P P$-expressing mouse islets were transduced with AdProhIAPP-siRNA to suppress hIAPP production, thereby preventing amyloid formation [4]. Non-transduced and transduced human and mouse islets were then cultured in 11.1 and $16.7 \mathrm{mmol} / \mathrm{l}$ glucose, respectively, to potentiate amyloid formation. Islets transduced with Ad-Cont-siRNA, which had a non-specific siRNA, were used as a control to detect any potential adverse effects of adenoviral transduction on beta cells. As expected [16, 48], hIAPP-expressing mouse islets formed amyloid during culture and had a higher rate of beta cell apoptosis than wild-type islets (Fig. 4). Interestingly, the aggregation of endogenously produced hIAPP in cultured $\mathrm{h} I A P P$-expressing mouse islets was associated with Fas upregulation in beta cells (Fig. 4a) and increased islet IL-1 $\beta$ levels (Fig. 4b). Adenoviral siRNA-mediated suppression of $\mathrm{h} I A P P$ expression markedly reduced amyloid formation, islet IL-1 $\beta$ levels, beta cell Fas upregulation and apoptosis. Similarly, the formation of hIAPP aggregates in human islets during culture was associated with the upregulation of Fas in beta cells and increased islet IL-1 $\beta$ levels (Fig. 5), both of which were reduced by adenoviral-siRNA-mediated suppression of amyloid formation. Transduction with control adenovirus (Ad-Cont-siRNA) had no noticeable effect on amyloid formation or beta cell survival in human or $\mathrm{h} I A P P$-expressing mouse islets.

Fig. 3 Culture with islet amyloid inhibitor or a Fas antagonist, or deletion of Fas in islet beta cells markedly reduces apoptosis induced by exogenously applied hIAPP. a INS-1 cells treated with hIAPP $(10 \mu \mathrm{mol} / \mathrm{l}, 12 \mathrm{~h})$ without or with Congo red (CR; $25 \mu \mathrm{mol} / \mathrm{l})$ were immunolabelled for insulin (red) and Fas (green). b INS-1 and mouse islet cells were treated with hIAPP alone $(24 \mathrm{~h})$, or with CR or Kp7-6 (10 mmol/l), and immunolabelled for insulin (green) and TUNEL (red). The squares (dashed white lines) denote regions enlarged and depicted as insets at bottom right of the relevant images. c The proportion of cleaved caspase-3 (CASP-3) and TUNEL-positive INS1 cells treated with hIAPP (or rIAPP) in the absence and presence of CR or Kp7-6. Black bars, non-treated; white bars, rIAPP; grey bars, hIAPP; dotted bars, hIAPP+CR; hatched bars, hIAPP+Kp7-6. d The proportion of apoptotic mouse islet cells treated with hIAPP alone or with Kp7-6 for $24 \mathrm{~h}$. e hIAPP-treated RIP $c r e^{+} \mathrm{Fas}^{\mathrm{fl} / \mathrm{fl}}$ and wild-type $\left(\mathrm{RIPCre}^{+} \mathrm{Fas}^{+/+}\right.$) mouse islet cells immunolabelled for insulin (red) and Fas (green). The squares (white outline) denote regions enlarged in each image. Fas-positive beta cells were present in hIAPP-treated wildtype islet cells, but not in mouse islet cells with beta cell Fas deletion. A low number of Fas-positive non-beta cells was detected in wild-type and $F a s^{\text {fl/fl }}$ islet cells. $\mathbf{f}$ The proportion of apoptotic beta cells in mouse islet cells with and without Fas deletion after treatment with hIAPP $(24 \mathrm{~h})$. The proportion of apoptotic beta cells was quantified by manual counting of double insulin- and cleaved caspase-3- or TUNEL-positive INS- 1 or islet cells in a minimum of ten microscopic fields, each containing 200 to 300 INS-1 cells or 100 to 150 dispersed islet cells. Results $(\mathbf{c}, \mathbf{d}, \mathbf{f})$ are expressed as means \pm SEM of three independent studies performed in triplicate; ${ }^{*} p<0.05$ by one-way ANOVA vs nontreated groups; $\uparrow p<0.05$ by one-way ANOVA vs hIAPP alone group; $\ddagger p<0.05$ by one-way ANOVA vs Fas-expressing hIAPP-treated group 
Beta cell-specific deletion of Fas in hIAPP-expressing transgenic mouse islets markedly reduces apoptosis induced by the aggregation of endogenously produced hIAPP during culture We generated a mouse model with beta cell-specific expression of $\mathrm{h} I A P P$ and deletion of Fas (RIPcre ${ }^{+} \mathrm{Fas}^{\mathrm{fl} / \mathrm{fl}}$ / $\left.\mathrm{h} I A P P^{+}\right)$by cross-breeding $\mathrm{h} I A P P$-expressing mice with $\mathrm{RIPCre}^{+} \mathrm{Fas}^{\mathrm{fl} / \mathrm{fl}}$ mice. Our aim was to further examine the role of Fas in beta cell apoptosis induced by the hIAPP a

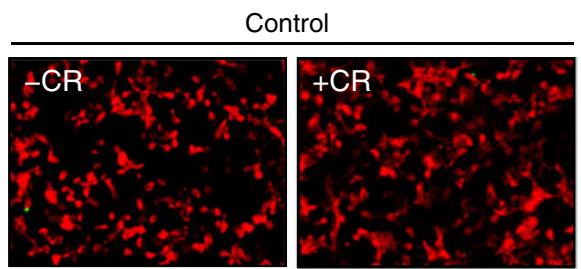

b
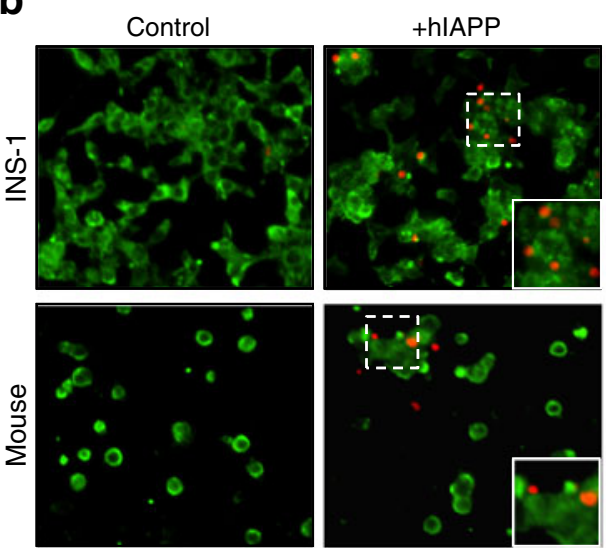

C

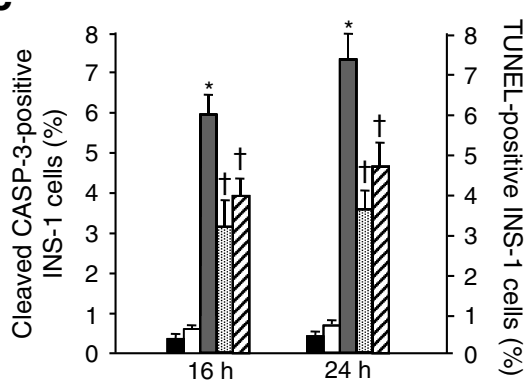

e

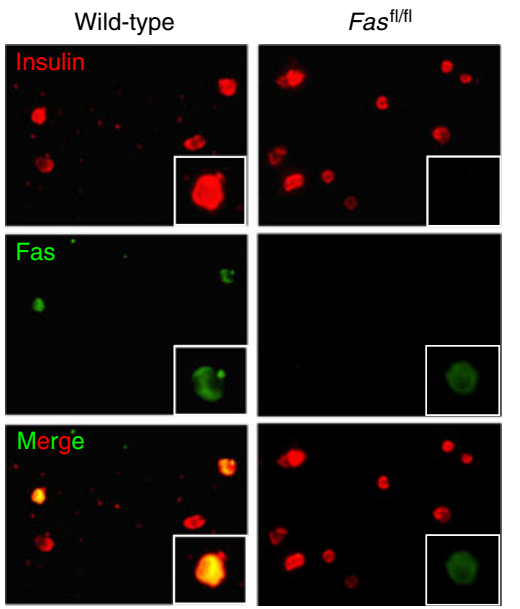

+hIAPP

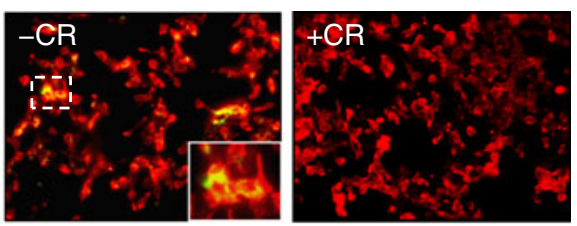

$+\mathrm{hlAPP}+\mathrm{CR}$

+hIAPP+FA
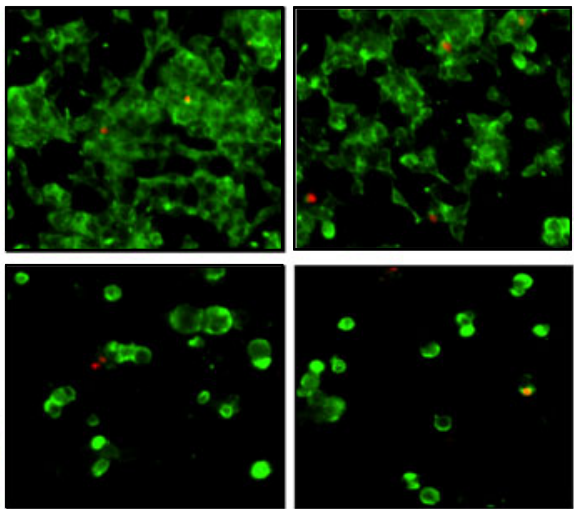

d
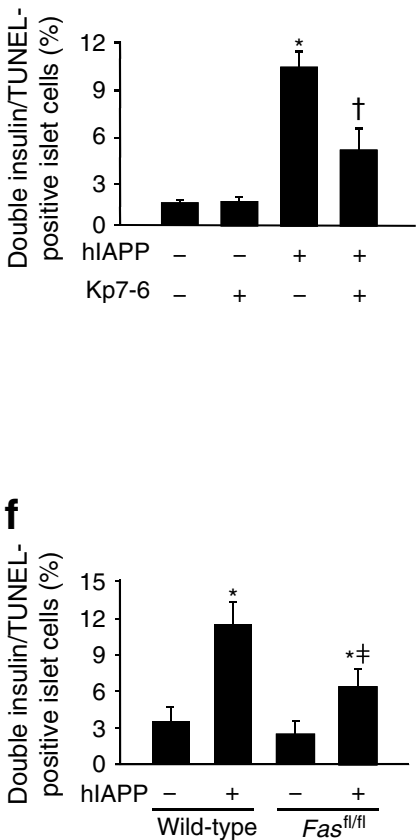
Fig. 4 Suppression of islet amyloid formation in cultured $\mathrm{h} / A P P$-expressing mouse islets reduces IL- $1 \beta$ levels, Fas upregulation and beta cell apoptosis. Islets isolated from $\mathrm{h} I A P P^{+}$transgenic mice ( 8 to 12 weeks old) were transduced overnight with Ad-Proh $I A P P$ siRNA or Ad-Cont-siRNA (as control). Non-transduced and transduced islets were cultured in Ham's-F10 ( $16.7 \mathrm{mmol} / \mathrm{l}$ glucose) for 6 days to allow amyloid formation. Paraffin-embedded islet sections were immunolabelled for: (a) insulin (Ins; red) and thioflavin S (Thio; blue), or insulin (red) and Fas (green) as indicated; and (b) insulin (red) and thioflavin $S$ (blue), or insulin (red) and IL-1 $\beta$ (green) as indicated. The squares (dashed white outline) denote regions enlarged and depicted as insets at bottom right of the relevant images. $\mathbf{c}$ The percentage of thioflavin S (amyloid)positive islets in non-transduced and transduced islets with AdProh $I A P P$-siRNA or Ad-ContsiRNA after 6 days of culture. $\mathbf{d}$ The proportion of apoptotic beta cells in islets as above (c). The number of double insulin- and TUNEL-positive islet cells was counted in each islet in a total of 15 to 20 islets from each condition. Results are expressed as means \pm SEM of three independent studies; ${ }^{*} p<0.05$ by one-way ANOVA vs corresponding non-transduced group a
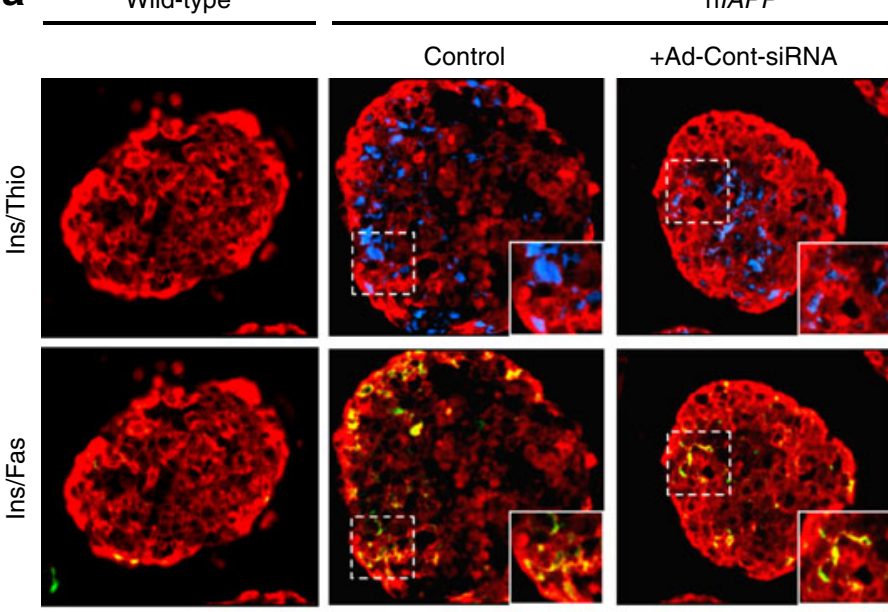

+Ad-ProhIAPP-siRNA

b
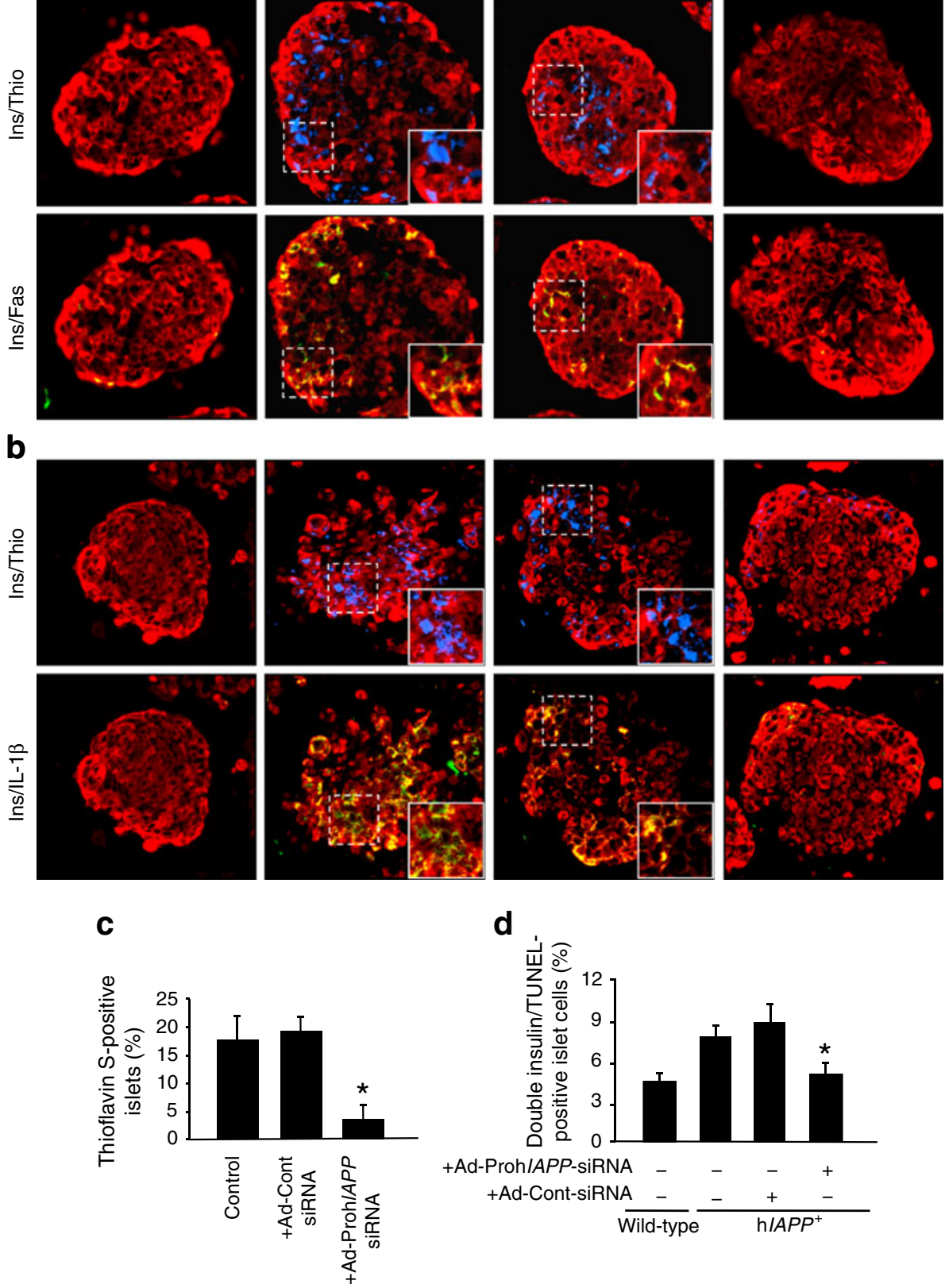

d

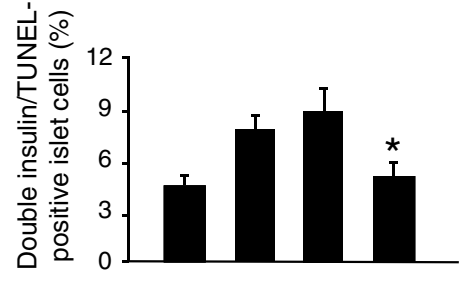

+Ad-ProhIAPP-siRNA - $\quad-\quad-\quad+$

+ Wild-type $\frac{-}{\mathrm{h} / A P P^{+}}$ aggregates that are formed by endogenously produced hIAPP in islets. Islets from RIP $\mathrm{Cre}^{+} \mathrm{Fas}^{+/+} / \mathrm{h} I A P P^{-/-}$and RIP $c r e^{+} F{ }^{\mathrm{fl}}{ }^{\mathrm{fl} l} / \mathrm{h} I A P P^{-/-}$mice were used as controls to detect any hIAPP-independent effects of Fas deletion on beta cell apoptosis. Cultured islets from RIPcre $\mathrm{Fas}^{\mathrm{fl} / \mathrm{fl}} / \mathrm{h} I A P P^{+}$ and RIP $\mathrm{Cre}^{+} \mathrm{Fas}^{+/+} / \mathrm{h} \mathrm{APPP}{ }^{+}$mice had comparable levels of amyloid formation (Fig. 6a, b). Basal beta cell death in $\mathrm{RIP}_{\mathrm{Cre}} \mathrm{Fas}^{\mathrm{fl} / \mathrm{fl}}$ mice was somewhat lower than in wild-type mice, but this difference was not statistically significant (Fig. 6c). Despite similar levels of amyloid formation, islets

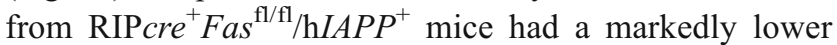

number of active caspase-3 and TUNEL-positive beta cells than RIPcre ${ }^{+} \mathrm{Fas}^{+/+} / \mathrm{h} / A P P^{+}$islets, but a comparable number of alpha cells (Fig. 6a, c), resulting in a higher islet beta:alpha

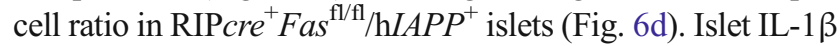
immunoreactivity was markedly higher in $\mathrm{h} I A P P$-expressing mouse islets with amyloid formation than in wildtype islets (Fig. 6a).

Reduced amyloid-induced beta cell death in hIAPP-expressing transgenic mouse islets with Fas deletion is associated with enhanced beta cell function Amyloid formation in $\mathrm{h} I A P P$ - 
a
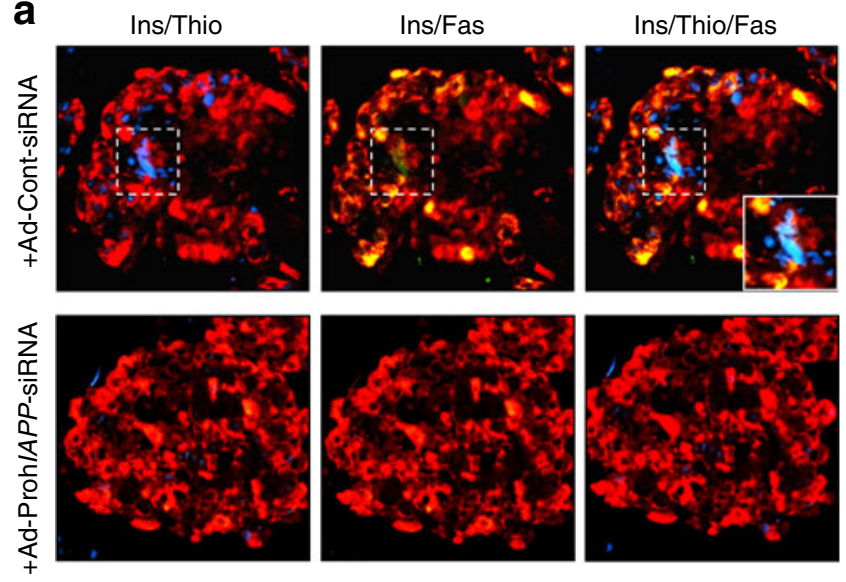

b
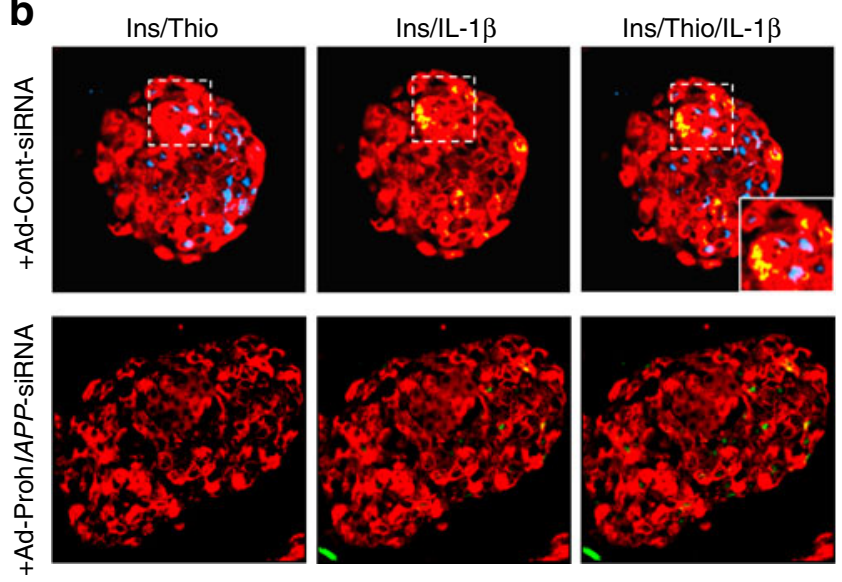

Fig. 5 Adenoviral-siRNA-mediated suppression of islet amyloid formation in cultured human islets reduces IL- $1 \beta$ levels and Fas upregulation, and enhances beta cell survival. Isolated human islets were transduced overnight with Ad-Proh $I A P P$-siRNA or Ad-Cont-siRNA (as control). Transduced islets were cultured for 7 days in CMRL containing $11.1 \mathrm{mmol} / 1$ glucose to allow amyloid formation. Paraffinembedded islet sections from cultured islets transduced as indicated were immunolabelled for (a) insulin (Ins; red), Fas (green) and thioflavin S (Thio; blue), and (b) for insulin (Ins; red), IL-1 $\beta$ (green) and thioflavin S (Thio; blue). Note the higher Fas and islet IL-1 $\beta$ immunoreactivity in thioflavin $\mathrm{S}$ (amyloid)-positive islets compared with islets in which amyloid formation was suppressed. Images are representative of studies performed on three human islet preparations

expressing mouse islets during culture was associated with lower islet insulin content and glucose-stimulated insulin release, and higher proinsulin release than in wild-type islets (Fig. 7). This resulted in a higher proinsulin:insulin secretion ratio from $\mathrm{h} I A P P$-expressing islets than from wild-type islets. Glucose-stimulated insulin release was increased by $28 \%$ and proinsulin release was reduced by $18 \%$ in $\mathrm{h} I A P P$ expressing mouse islets with beta cell Fas deletion compared with islets expressing Fas. These findings suggest that Fas deletion in $\mathrm{h} I A P P$-expressing mouse islets enhances insulin secretion and improves the ratio of proinsulin:insulin released from islets. Deletion of Fas in hIAPP-expressing mouse islets did not have any significant effect on islet insulin or proinsulin content during 7 days of culture. Finally, glucose-stimulated insulin release was somewhat higher in non-transgenic $\left(\mathrm{h} L A P P^{-/-}\right)$islets with $F$ as deletion than in non-transgenic islets expressing Fas, but this difference was not statistically significant.

\section{Discussion}

Growing evidence suggests that the formation of hIAPP aggregates in pancreatic islets of patients with type 2 diabetes, cultured human islets and human islet grafts is associated with progressive beta cell dysfunction and death [1-3]. Beta cell-toxic effects of hIAPP aggregates are likely to be mediated through similar mechanisms in all conditions associated with islet amyloid formation. As yet, however, the molecular mechanisms by which the aggregation of biosynthetic hIAPP induces beta cell apoptosis are not well understood. Previous studies have shown that amyloid formation in human [4] and $\mathrm{h} I A P P$-expressing mouse islets [16] increases beta cell apoptosis, and that prevention of amyloid formation enhances survival and function of human islets [4]. We further demonstrated that prevention of caspase-3 activation protects islet beta cells from apoptosis induced by fibrillogenesis of hIAPP produced and secreted from islet beta cells [27].

In the present study, using two ex vivo models of islet amyloid formation, cultured human islets and hIAPPexpressing mouse islets with beta cell-specific Fas deletion, we show that Fas has a key role in the beta cell apoptosis induced by aggregation of the biosynthetic hIAPP produced by islet beta cells. We also show that prevention of hIAPPinduced Fas upregulation or deletion of Fas protects islet beta cells from the hIAPP aggregates formed during in situ islet culture. These findings suggest that aggregation of biosynthetic hIAPP induces beta cell apoptosis, at least partially, through the Fas receptor and the Fas-mediated apoptotic pathway.

Consistent with a previous in vitro study performed on beta cells [26], we found that micromolar concentrations of synthetic hIAPP induces Fas upregulation in INS-1 cells, as well as in human and mouse islet beta cells, in a timedependent manner. The majority of Fas-positive islet cells were beta cells, suggesting that hIAPP-induced upregulation of Fas is beta cell-specific. Furthermore, our immunolabelling studies showed a clear co-localisation of Fas and active caspase-3 in INS-1 and dispersed islet beta cells. Finally, culture in the presence of a Fas antagonist or deletion of Fas in islet beta cells significantly reduced hIAPP-induced apoptosis. Taken together, these findings suggest that in transformed and primary islet beta cells, exposure to hIAPP aggregates derived from exogenously applied hIAPP induces upregulation of Fas and that hIAPP-induced Fas upregulation 
a

$\mathrm{h} / \mathrm{APP}^{+} / \mathrm{Fas}^{+/+}$

$\mathrm{h} / A P P^{+} / F^{f t} s^{\mathrm{t} / f \mathrm{l}}$

$\mathrm{h} / \mathrm{APP}^{-} / \mathrm{Fas}^{+/+}$

$\mathrm{h} / A P P^{-} /$Fas $^{\mathrm{f} / / \mathrm{fl}}$
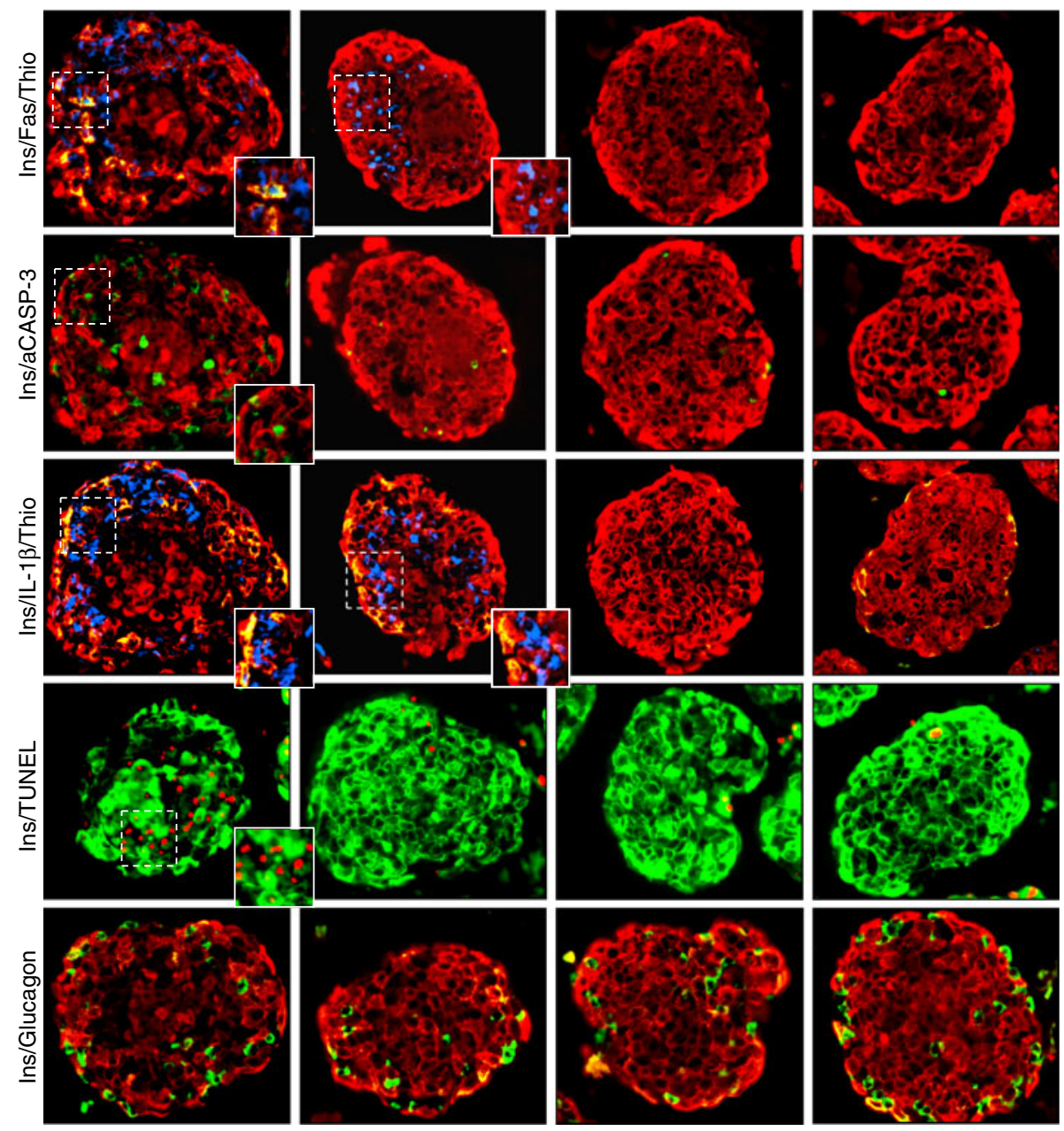

b

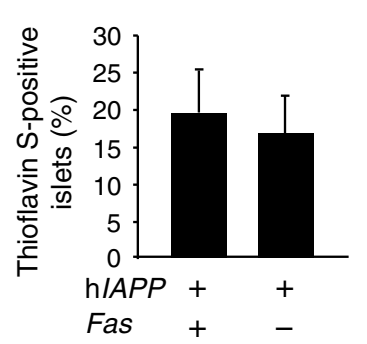

C

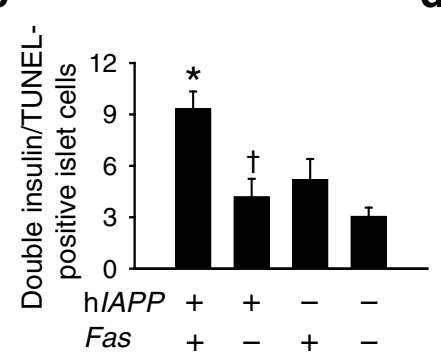

d

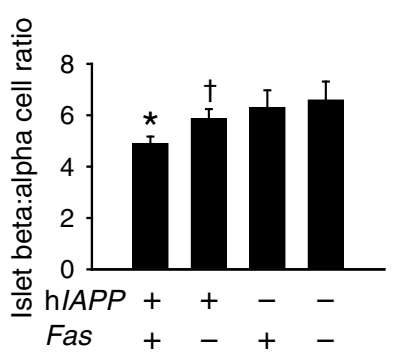

Fig. 6 Beta cell-specific deletion of Fas in h $L A P P$-expressing transgenic mouse islets markedly reduces apoptosis induced by the aggregation of endogenously produced hIAPP during culture. Freshly isolated islets from wild-type (RIP $\mathrm{Cre}^{+} \mathrm{Fas}^{+/+}$), RIP $\mathrm{Rre}^{+} \mathrm{Fas}^{\mathrm{fl} / \mathrm{fl}}$, and $\mathrm{h} I A P P$ transgenic mice expressing (RIP $\mathrm{Cre}^{+} \mathrm{Fas}^{+++} / \mathrm{h} I A P P^{+}$) or lacking

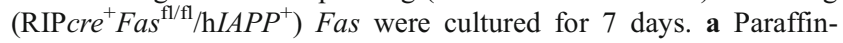
embedded sections of cultured islets from wild-type and $\mathrm{h} I A P P$ expressing mice ( 8 to 18 weeks old) with or without Fas deletion were double immunolabelled as indicated for: insulin (Ins; red), Fas (green), and thioflavin S (Thio; blue); insulin (red) and cleaved (active) caspase-3 (aCASP-3; green); insulin (red), IL-1 $\beta$ (green) and thioflavin S (blue); insulin (green) and TUNEL (red); and insulin (red) and glucagon (Glu; green). The squares (dashed white outline) denote regions enlarged and depicted as insets at bottom right of the relevant images. b The percentage of thioflavin $\mathrm{S}$ (amyloid)-positive $\mathrm{h} I A P P$ expressing islets with or without Fas deletion after 7 days of culture. c The proportion of TUNEL-positive beta cells and (d) the islet beta: alpha cell ratio were quantified following triple insulin/TUNEL/DAPI or insulin/glucagon/DAPI staining, respectively. The number of double insulin- and TUNEL-positive islet cells (c) was counted in each islet in a total of 15 to 25 islets per animal from each genotype (six to eight animals per group). Islet beta:alpha cell ratio (d) represents the mean of insulin-positive cells divided by glucagon-positive cells in each islet. Results (b-d) are presented as mean \pm SEM; ${ }^{*} p<0.05$ by one-way ANOVA vs wild-type group; $\dagger p<0.05$ by one-way ANOVA vs corresponding $\mathrm{Fas}$-expressing group 


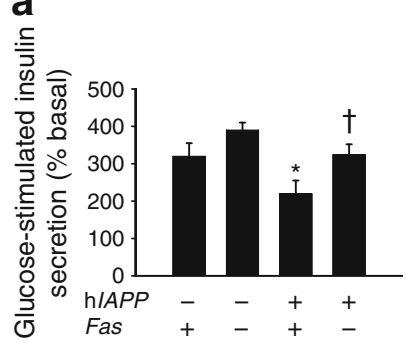

b
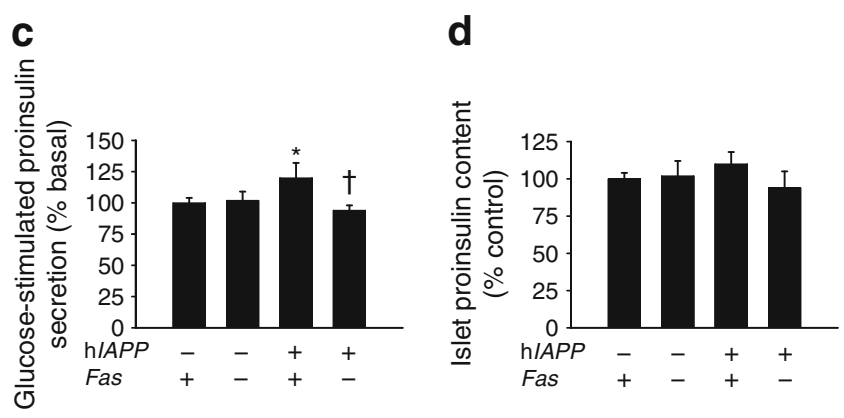

Fig. 7 Reduced amyloid-induced beta cell death in $\mathrm{h} I A P P$-expressing transgenic mouse islets with Fas deletion is associated with enhanced beta cell function. a Islet insulin response to glucose stimulation (16.7 mmol/1), (b) insulin content, (c) glucose-stimulated proinsulin release and (d) proinsulin content in 7-day cultured wild-type and hIAPP-expressing mouse islets with or without Fas deletion were assessed by the glucose-stimulated insulin secretion test as described (Methods). Islet insulin and proinsulin content are reported as percentage of insulin or proinsulin content in cultured wild-type islets taken as $100 \%$. Glucose-stimulated insulin or proinsulin release is depicted as fold increase over basal release $(1.67 \mathrm{mmol} / 1$ glucose $)$. Results are expressed as means \pm SEM of four to six animals per genotype; ${ }^{*} p<$ 0.05 by one-way ANOVA vs wild-type group; $\uparrow p<0.05$ by one-way ANOVA vs corresponding Fas-expressing group

is associated with caspase-3 activation and subsequent beta cell apoptosis.

Under normal conditions, INS-1 cells did not produce Fas at levels detectable with the immunolabelling techniques used by us. Unlike INS-1 cells, however, low numbers of beta and non-beta Fas-positive islet cells were present in dispersed human and mouse islets. It is possible that cytokines or other Fas-inducing factors that are released from islet cells and other cells in the digested pancreatic tissue during islet isolation and culture contribute to the low levels of Fas detected in non-treated islet cells. Consistent with our findings, IL-1 $\beta$ and elevated glucose have been reported to induce Fas upregulation in islet beta cells [43, 44]. Finally, islet amyloid and elevated glucose, both of which contribute to beta cell death in type 2 diabetes, may induce Fas upregulation in an additive manner.

Treatment of INS-1 cells with the amyloid binding dye, Congo red, which prevents amyloid formation and its interaction with beta cell membranes, markedly reduced hIAPPinduced Fas upregulation and the proportion of active caspase- 3 and apoptotic beta cells. These findings support the notion that interaction of extracellular hIAPP aggregates with beta cell membranes is important for Fas upregulation and subsequent beta cell apoptosis, and that inhibitors of islet amyloid may provide a way of preventing amyloidinduced Fas upregulation.

To examine whether the hIAPP aggregates formed by biosynthetic hIAPP produced and secreted from islet beta cells can induce Fas upregulation, we used human and transgenic mouse islets with beta cell $\mathrm{h} I A P P$ expression as two ex vivo models of islet amyloid formation [4, 16, 48]. Human and hIAPP-expressing mouse islets, but not wildtype mouse islets formed hIAPP aggregates during culture, this being associated with upregulation of Fas. Immunolabelling studies showed that Fas-positive islet areas colocalised with thioflavin S (amyloid)-positive islet areas, indicating the correlation between amyloid formation and Fas upregulation. Furthermore, the prevention of amyloid formation in human and $\mathrm{h} I A P P$-expressing mouse islets by Ad-Proh $I A P P$-siRNA markedly reduced Fas upregulation and subsequent beta cell apoptosis.

We also generated a mouse model expressing $\mathrm{h} I A P P$ with beta cell-specific Fas deletion to further investigate the role of Fas in mediating the beta cell-toxic effects of endogenously produced hIAPP aggregates in islets. Islets from hIAPP-expressing mice with or without Fas deletion had comparable levels of amyloid formation, confirming that the absence of Fas as such does not have any significant effect on amyloid formation in $\mathrm{h} I A P P$-expressing mouse islets. Interestingly, $\mathrm{h} I A P P$-expressing mouse islets lacking Fas had significantly lower numbers of active caspase- 3 and apoptotic beta cells, a higher islet insulin response to glucose and lower proinsulin release than islets expressing hIAPP and Fas, suggesting that deletion of Fas protects islet beta cells from endogenously produced hIAPP aggregates and improves their survival and function. Enhanced insulin secretion in $\mathrm{h} I A P P$-expressing mouse islets with beta cell Fas deletion is likely to be due to the reduction of hIAPP-induced beta cell apoptosis mediated by Fas upregulation and to the effects of Fas deletion on beta cell secretion [47]. Importantly, despite significant increases in the proportion of active caspase-3 and apoptotic beta cells, the number of alpha cells remained unchanged in cultured $\mathrm{h} I A P P$-transgenic mouse islets expressing Fas, resulting in a lower beta:alpha cell ratio in $\mathrm{h} I A P P$-expressing mouse islets with Fas expression than in those lacking Fas.

The formation of hIAPP-aggregates and upregulation of Fas in human and $\mathrm{h} I A P P$-expressing mouse islets was associated with increased islet IL-1 $\beta$ immunoreactivity, which was reduced by adenoviral-siRNA-mediated prevention of amyloid formation, suggesting that IL-1 $\beta$ may contribute to hIAPPinduced Fas upregulation. The source of IL- $1 \beta$ detected by immunolabelling in thioflavin $\mathrm{S}$ (amyloid)-positive islets 
might be islet beta cells, non-beta cells or non-islet cells. In support of this notion, beta cells have been shown to produce IL- $1 \beta$ in conditions such as exposure to elevated glucose resulting in upregulation of Fas [44]. Furthermore, two recent studies have demonstrated the release of IL-1 $\beta$ from non-islet cells such as macrophages activated by hIAPP aggregates [ 49 , 50]. Taken together, these findings support a role for IL- $1 \beta$ in hIAPP-induced Fas upregulation, although further studies are required to identify the cell types that release IL- $1 \beta$ in conditions associated with islet amyloid formation.

In summary, our studies show that hIAPP-induced beta cell death is mediated, at least partially, via upregulation of Fas and activation of the Fas-mediated apoptotic pathway. We also show that deletion of Fas protects islet beta cells from the cytotoxic effects of endogenously secreted (and exogenously applied) hIAPP. Preventing the interaction between hIAPP aggregates and beta cells, or blocking Fas could constitute new ways to avoid amyloid toxicity and thereby enhance survival and function of human islets in conditions associated with islet amyloid formation, such as type 2 diabetes, islet culture, and transplantation.

Acknowledgements Human IAPP transgenic mice for these studies were kindly provided by S. Kahn (Department of Medicine, VA Puget Sound Health Care System and University of Washington, Seattle, WA, USA). Human islets were provided by the Ike Barber Human Islet Transplant Laboratory (Vancouver, BC, Canada). We gratefully acknowledge the outstanding technical assistance of I. Barta, A. Asadi and G. Soukhatcheva to the completion of these studies.

Funding This work was supported by grants from the Canadian Institutes of Health Research (CIHR) to L. Marzban (MOP-81375) and M. Woo (MOP-201188). Y.J. Park is supported by a studentship from the CIHR Transplantation Training Program. L. Marzban is a Scholar of the Canadian Diabetes Association and T.J. Kieffer is a Michael Smith Foundation for Health Research (MSFHR) Senior Scholar. Infrastructure support was provided by grants from the Canadian Foundation for Innovation (to L. Marzban) and the MSFHR to the Centre for Human Islet Transplantation and Beta Cell Regeneration (G.L. Warnock).

Contribution statement All authors contributed to the conception and design, or analysis and interpretation of data, and to the drafting of the article or its critical revision for important intellectual content. All authors gave final approval of the version to be published.

Duality of interest The authors declare that there is no duality of interest associated with this manuscript.

\section{References}

1. Haataja L, Gurlo T, Huang CJ, Butler PC (2008) Islet amyloid in type 2 diabetes, and the toxic oligomer hypothesis. Endocr Rev 29:303-316

2. Westermark P, Andersson A, Westermark GT (2011) Islet amyloid polypeptide, islet amyloid, and diabetes mellitus. Physiol Rev 91:795-826
3. Jurgens CA, Toukatly MN, Fligner CL et al (2011) Beta-cell loss and beta-cell apoptosis in human type 2 diabetes are related to islet amyloid deposition. Am J Pathol 178:2632-2640

4. Marzban L, Tomas A, Becker TC et al (2008) Small interfering RNA-mediated suppression of proislet amyloid polypeptide expression inhibits islet amyloid formation and enhances survival of human islets in culture. Diabetes 57:3045-3055

5. Westermark P, Eizirik DL, Pipeleers DG, Hellerstrom C, Andersson A (1995) Rapid deposition of amyloid in human islets transplanted into nude mice. Diabetologia 38:543-549

6. Westermark G, Westermark P, Eizirik DL et al (1999) Differences in amyloid deposition in islets of transgenic mice expressing human islet amyloid polypeptide versus human islets implanted into nude mice. Metabolism 48:448-454

7. Potter KJ, Abedini A, Marek P et al (2010) Islet amyloid deposition limits the viability of human islet grafts but not porcine islet grafts. Proc Natl Acad Sci USA 107:4305-4310

8. Westermark GT, Westermark P, Berne C, Korsgren O (2008) Widespread amyloid deposition in transplanted human pancreatic islets. N Engl J Med 359:977-979

9. Udayasankar J, Kodama K, Hull RL et al (2009) Amyloid formation results in recurrence of hyperglycaemia following transplantation of human IAPP transgenic mouse islets. Diabetologia 52:145-153

10. Westermark P, Wernstedt C, Wilander E, Hayden DW, O'Brien TD, Johnson KH (1987) Amyloid fibrils in human insulinoma and islets of Langerhans of the diabetic cat are derived from a neuropeptide-like protein also present in normal islet cells. Proc Natl Acad Sci USA 84:3881-3885

11. Cooper GJ, Willis AC, Clark A, Turner RC, Sim RB, Reid KB (1987) Purification and characterization of a peptide from amyloidrich pancreases of type 2 diabetic patients. Proc Natl Acad Sci USA 84:8628-8632

12. Verchere CB, D'Alessio DA, Prigeon RL, Hull RL, Kahn SE (2000) The constitutive secretory pathway is a major route for islet amyloid polypeptide secretion in neonatal but not adult rat islet cells. Diabetes 49:1477-1484

13. Marzban L, Trigo-Gonzalez G, Verchere CB (2005) Processing of pro-islet amyloid polypeptide in the constitutive and regulated secretory pathways of beta cells. Mol Endocrinol 19:2154-2163

14. Westermark P, Engstrom U, Johnson KH, Westermark GT, Betsholtz C (1990) Islet amyloid polypeptide: pinpointing amino acid residues linked to amyloid fibril formation. Proc Natl Acad Sci USA 87:5036-5040

15. Hou X, Ling Z, Quartier E et al (1999) Prolonged exposure of pancreatic beta cells to raised glucose concentrations results in increased cellular content of islet amyloid polypeptide precursors. Diabetologia 42:188-194

16. Marzban L, Rhodes CJ, Steiner DF, Haataja L, Halban PA, Verchere CB (2006) Impaired NH2-terminal processing of human pro-islet amyloid polypeptide by the prohormone convertase PC2 leads to amyloid formation and cell death. Diabetes 55:21922201

17. Paulsson JF, Westermark GT (2005) Aberrant processing of human proislet amyloid polypeptide results in increased amyloid formation. Diabetes 54:2117-2125

18. Nyqvist D, Kohler M, Wahlstedt H, Berggren PO (2005) Donor islet endothelial cells participate in formation of functional vessels within pancreatic islet grafts. Diabetes 54:2287-2293

19. Klimek AM, Soukhatcheva G, Thompson DM et al (2009) Impaired proinsulin processing is a characteristic of transplanted islets. Am J Transplant 9:2119-2125

20. Ritzel RA, Meier JJ, Lin CY, Veldhuis JD, Butler PC (2007) Human islet amyloid polypeptide oligomers disrupt cell coupling, induce apoptosis, and impair insulin secretion in isolated human islets. Diabetes 56:65-71 
21. Last NB, Rhoades E, Miranker AD (2011) Islet amyloid polypeptide demonstrates a persistent capacity to disrupt membrane integrity. Proc Natl Acad Sci USA 108:9460-9465

22. Engel MF, Khemtemourian L, Kleijer CC et al (2008) Membrane damage by human islet amyloid polypeptide through fibril growth at the membrane. Proc Natl Acad Sci USA 105:6033-6038

23. Quist A, Doudevski I, Lin H et al (2005) Amyloid ion channels: a common structural link for protein-misfolding disease. Proc Natl Acad Sci USA 102:10427-10432

24. Rumora L, Hadzija M, Barisic K, Maysinger D, Grubiic TZ (2002) Amylin-induced cytotoxicity is associated with activation of caspase-3 and MAP kinases. Biol Chem 383:1751-1758

25. Zhang S, Liu J, Dragunow M, Cooper GJ (2003) Fibrillogenic amylin evokes islet beta-cell apoptosis through linked activation of a caspase cascade and JNK1. J Biol Chem 278:52810-52819

26. Zhang S, Liu H, Yu H, Cooper GJ (2007) Fas-associated death receptor signaling evoked by human amylin in islet beta-cells. Diabetes 57:348-356

27. Law E, Lu S, Kieffer TJ et al (2010) Differences between amyloid toxicity in alpha and beta cells in human and mouse islets and the role of caspase-3. Diabetologia 53:1415-1427

28. Young ID, Ailles L, Narindrasorasak S, Tan R, Kisilevsky R (1992) Localization of the basement membrane heparan sulfate proteoglycan in islet amyloid deposits in type II diabetes mellitus. Arch Pathol Lab Med 116:951-954

29. Park K, Verchere CB (2001) Identification of a heparin binding domain in the N-terminal cleavage site of pro-islet amyloid polypeptide. Implications for islet amyloid formation. J Biol Chem 276:16611-16616

30. Casas S, Novials A, Reimann F, Gomis R, Gribble FM (2008) Calcium elevation in mouse pancreatic beta cells evoked by extracellular human islet amyloid polypeptide involves activation of the mechanosensitive ion channel TRPV4. Diabetologia 51:2252-2262

31. Zheng X, Ren W, Zhang S et al (2010) Serum levels of proamylin and amylin in normal subjects and patients with impaired glucose regulation and type 2 diabetes mellitus. Acta Diabetol 47:265-270

32. Huang CJ, Lin CY, Haataja L et al (2007) High expression rates of human islet amyloid polypeptide induce endoplasmic reticulum stress mediated beta-cell apoptosis, a characteristic of humans with type 2 but not type 1 diabetes. Diabetes 56:2016-2027

33. Matveyenko AV, Gurlo T, Daval M, Butler AE, Butler PC (2009) Successful versus failed adaptation to high fat diet induced insulin resistance; the role of IAPP induced beta cell endoplasmic reticulum stress. Diabetes 58:906-916

34. Costes S, Huang CJ, Gurlo T et al (2011) Beta-cell dysfunctional ERAD/ubiquitin/proteasome system in type 2 diabetes mediated by islet amyloid polypeptide-induced UCH-L1 deficiency. Diabetes 60:227-238
35. Zraika S, Hull RL, Udayasankar J et al (2009) Oxidative stress is induced by islet amyloid formation and time-dependently mediates amyloid-induced beta cell apoptosis. Diabetologia 52:626-635

36. Rivera JF, Gurlo T, Daval M et al (2011) Human-IAPP disrupts the autophagy/lysosomal pathway in pancreatic beta-cells: protective role of p62-positive cytoplasmic inclusions. Cell Death Differ 18:415-426

37. Nagata S, Golstein P (1995) The Fas death factor. Science 267:1449-1456

38. Pearl-Yafe M, Yolcu ES, Yaniv I, Stein J, Shirwan H, Askenasy N (2006) The dual role of Fas-ligand as an injury effector and defense strategy in diabetes and islet transplantation. Bioessays 28:211-222

39. Gloire G, Charlier E, Piette J (2008) Regulation of CD95/APO-1/ Fas-induced apoptosis by protein phosphatases. Biochem Pharmacol 76:1451-1458

40. Moriwaki M, Itoh N, Miyagawa J et al (1999) Fas and Fas ligand expression in inflamed islets in pancreas sections of patients with recent-onset type I diabetes mellitus. Diabetologia 42:1332-1340

41. Chervonsky AV, Wang Y, Wong FS et al (1997) The role of Fas in autoimmune diabetes. Cell 89:17-24

42. Hanafusa T, Imagawa A (2008) Insulitis in human type 1 diabetes. Ann N Y Acad Sci 1150:297-299

43. Maedler K, Spinas GA, Lehmann R et al (2001) Glucose induces beta-cell apoptosis via upregulation of the Fas receptor in human islets. Diabetes 50:1683-1690

44. Maedler K, Sergeev P, Ris F et al (2002) Glucose-induced beta cell production of IL-1beta contributes to glucotoxicity in human pancreatic islets. J Clin Invest 110:851-860

45. Maedler K, Sergeev P, Ehses JA et al (2004) Leptin modulates beta cell expression of IL-1 receptor antagonist and release of IL-1beta in human islets. Proc Natl Acad Sci USA 101:8138-8143

46. Verchere CB, D'Alessio DA, Palmiter RD et al (1996) Islet amyloid formation associated with hyperglycemia in transgenic mice with pancreatic beta cell expression of human islet amyloid polypeptide. Proc Natl Acad Sci USA 93:3492-3496

47. Choi D, Radziszewska A, Schroer SA et al (2009) Deletion of Fas in the pancreatic beta-cells leads to enhanced insulin secretion. Am J Physiol Endocrinol Metab 297:E1304-E1312

48. Zraika S, Hull RL, Udayasankar J et al (2007) Glucose- and timedependence of islet amyloid formation in vitro. Biochem Biophys Res Commun 354:234-239

49. Westwell-Roper C, Dai DL, Soukhatcheva G et al (2011) IL-1 blockade attenuates islet amyloid polypeptide-induced proinflammatory cytokine release and pancreatic islet graft dysfunction. J Immunol 187:2755-2765

50. Masters SL, Dunne A, Subramanian SL et al (2010) Activation of the NLRP3 inflammasome by islet amyloid polypeptide provides a mechanism for enhanced IL-1beta in type 2 diabetes. Nat Immunol 11:897-904 